Original Research Paper

\title{
Utilization of Sewage Sludge in Agricultural Soil as Fertilizer in the Republic of Benin (West Africa): What are the Risks of Heavy Metals Contamination and Spreading?
}

\author{
${ }^{1}$ Fidèle Suanon, ${ }^{2}$ Lyde A.S. Tomètin, ${ }^{1,4}$ Biaou Dimon, \\ ${ }^{1}$ Ignace C. Agani, ${ }^{2,3}$ Daouda Mama and ${ }^{1}$ Eni Coffi Azandegbe \\ ${ }^{1}$ Laboratory of Physical Chemistry, University of Abomey-Calavi, BP: 4521 Cotonou Benin, Benin \\ ${ }^{2}$ Laboratory of Inorganic Chemistry and Environment, University of Abomey-Calavi, BP: 4521 Cotonou Benin, Benin \\ ${ }^{3}$ Laboratory of Applied Hydrology, University of Abomey-Calavi, Calavi, 01 BP: 526 Cotonou Benin, Benin \\ ${ }^{4}$ Beninese Center for Scientifics Research and Technologies (CBRST), 03 BP 1665 Cotonou Benin, Benin
}

\section{Article history}

Received: 11-06-2015

Revised: 08-08-2015

Accepted: 02-01-2016

Corresponding Author:

Fidèle Suanon

Laboratory of Physical Chemistry, University of Abomey-Calavi, BP: 4521 Cotonou Benin, Benin

Email: officielsuanon@yahoo.com

\begin{abstract}
Biosolids are the treated organic residuals, also known as sewage sludge, which are generated from domestic wastewater treatment plants. It is an organic matter and nutrients [phosphorous $(\mathrm{P})$ and nitrogen $(\mathrm{N})$ ]-rich material. Due to these properties, it is has been reported to be a suitable fertilizer or soil amendment which can valuably replace synthesized NPK. Unfortunately, this matter is heavily loaded with inorganic pollutants, namely heavy metals which limit its land application. Here, we evaluated the quality of treated sewage sludge from Wastewater Treatment Plants (WWTP) in the republic of Benin; and assessed the eco-toxicological risks of heavy metals contamination and spreading related to the use of sludge as fertilizer in agriculture. Results revealed a slightly alkaline $(\mathrm{pH} \geq 6.5)$ and high electrical conductivity $\left(\mathrm{EC}>4 \mathrm{mS} \mathrm{cm}^{-1}\right)$ of the sludge. Heavy metals including $\mathrm{Cd}, \mathrm{Co}$, $\mathrm{Cu}, \mathrm{Zn}, \mathrm{Ni}, \mathrm{Cr}, \mathrm{Pb}, \mathrm{Fe}$ and $\mathrm{Mn}$ contents were at high level: 27.1, 18.6, 777.1, $1271.7,165.5,297.0,131.2,3184.0$ and $394.2 \mathrm{mg} \mathrm{kg}^{-1} \mathrm{DM}$, respectively. Further fractionation of metals showed high mobility of metals classified as follow: $\mathrm{Cu}>\mathrm{Cd}>\mathrm{Pb}>\mathrm{Cr}>\mathrm{Ni}>\mathrm{Fe}>\mathrm{Mn}>\mathrm{Co}>\mathrm{Zn}$. As a consequence, although the sludge is rich in organic matter and phosphorous, its high value of EC and heavy metals contents, with high mobility do not favor its used in agriculture soils. In addition, metals were enriched in the sludge; meaning that anthropogenic sources, human activities greatly contributed to the accumulation of metals in the sludge.
\end{abstract}

Keywords: Sewage Sludge, Heavy Metals, Chemical Fractionation, Mobility, Pollution

\section{Introduction}

Biosolids also known as sewage sludge are the treated organic residuals generated from domestic wastewater treatment plants. With development and population growth, the production of waste and sewage sludge steadily increases from a year to year across countries in the world. In advanced countries like China, over 11.2 million tons of dry sludge is generated (Chu et al., 2009); while Approximately $6 \times 10^{6}$ metric tons is reported in the U.S each year, of which about $60 \%$ is applied to agricultural soil and land application (WEF and NACWA, 2013). Sludge management has become a problem with growing importance due to it potentially environmental hazard and high cost for disposal. It has been reported to be an excellent fertilizer and a potential source of organic substances and essential nutrimental elements such as nitrogen and phosphorus for plants. As a consequence, sewage sludge can valuably replace synthetic N and $\mathrm{P}$ fertilizers (Kelter et al., 1997; Gao et al., 2008; Roca-Pérez et al., 2009). However, the potential of pathogen transmission and the presence of toxic and persistent organic chemicals and inorganic pollutants (heavy metals) in biosolids; have for the most part limited its valorization. Considerable amount of numerous biodegradable compounds is contained within 
sewage sludge which gives rise to secondary pollution (Lee and Han, 2013). Anaerobic digestion and aerobic composting technology are widely used for sludge stabilization. During both processes, some organic pollutants are well remediated; while common sludge treatment process such as anaerobic digestion or composting cannot remove heavy metals from sewage sludge (Chipasa, 2003). Metals can thus be accumulated in the sludge and its long-term application can affect the productivity of soils (McBride, 1995). Therefore it is critical to pay due attention to this matter for the sake of environment safety.

In the republic of Benin, the management of wastewater and sewage sludge remains a great challenge. Talking of wastewater treatment plant, there is only one well known WWTP existing in the republic of Benin, which is located in most populated town (Cotonou) of the country. Now, old of 25 years, the WWTP was supposed to treat the wastewater from 300,000 inhabitants; which is the equivalent of $180 \mathrm{~m}^{3}$ sludge/day. Nowadays, the population has grown up and the WWTP has to deal with wastewater 3 times greater $\left(600 \mathrm{~m}^{3}\right.$ sludge/day) than that it was supposed to normally deal with. Unfortunately, while the volume/quantity of wastewater knew a drastically increase, the capacity of the WWTP did not significantly increased. Such situation let put a doubt on the quality of the final effluent and produced sewage sludge. Besides, it is important to note that the WWTP was not built to treat and removed metals from sewage sludge. Yet, at the date, the sludge from the WWTP is already being used in agriculture as soil amendment. It would therefore be urgent to investigate the eco-toxicological risks that would be related to the use of sludge as agricultural fertilizer.

To our knowledge, no report on the risk of heavy metals contamination related to the use of sewage sludge from the WWTP in agricultural soils is reported in the republic of Benin these recent years. Therefore, the current work aims at first to investigate and quantify the of heavy metals including $\mathrm{Cd}, \mathrm{Co}, \mathrm{Cu}, \mathrm{Zn}, \mathrm{Ni}, \mathrm{Cr}, \mathrm{Pb}, \mathrm{Fe}$ and $\mathrm{Mn}$ contents in the treated sewage sludge; and secondly, to proceed to their sequential fractionation in order to evaluate the eco-toxicological risks related to the use of sludge as fertilizer in agriculture.

\section{Materials and Methods}

\section{Samples and Pretreatment}

Dewatered sewage sludge collected from municipal WWTP was used in this study. Collected sludge was primary air dry, then under the oven at $105^{\circ} \mathrm{C}$ until constant mass and water content was determined. After drying, sludge was ground in a mortar and passed through a sieved size $\leq 2 \mathrm{~mm}$. The sludge powder was stored in a plastic bag for further physicochemical characterization and heavy metals determination.

\section{Physicochemical Characterization}

Physical and chemical parameters included $\mathrm{pH}$, Electrical Conductivity (EC), organic Matter Contents (OM), Total Phosphorus (TP) and metals contents. pH and $\mathrm{EC}$ were determined in the supernatant of dissolved sludge sample in reagent water ratio $1 / 10(\mathrm{~m} / \mathrm{v})$ by the mean of a multi-parameters (HACH, HQ40d), OM was determined by weight ignition at $550^{\circ} \mathrm{C}$ for $5 \mathrm{~h}$. For TP determination, sludge sample was digested via aqua regia digestion according to ISO 11464, EN 12880 and quantify via Flow Injection Analysis (FIA).

\section{Metal Total Concentration}

Sludge sample was digested according to Dong et al. (2013). Briefly, a mixture (16 mL) of $\mathrm{HCl}(36 \%): \mathrm{HNO}_{3}$ (67\%): HF (49\%) ratio 4:1:1 (v: v: v) was added to $0.5 \mathrm{~g}$ of sludge sample. The mixture was brought to $110^{\circ} \mathrm{C}$ using a hot plat under hood and the digestion was performed until dryness. The residue was dissolved with $2 \%$ of $\mathrm{HNO}_{3}$, filtered and collected into $50 \mathrm{~mL}$ polyethylene centrifuge tube and finally brought up to the volume. Samples were stored at $4^{\circ} \mathrm{C}$ until analysis. Samples were in triplicate and the average values were used. Let's call $\mathrm{C}_{0}$ the concentration of a given metal.

\section{Sequential Fractionation}

Sequential fractionation of metals was performed according to the modified method of Tessier et al. (1979) as reported by Aikpokpodion et al. (2013) (Table 1). Metals, in all extracted samples were determined using Atomic Adsorption Spectroscopy (AAS). Samples were in triplicate and the average values were used.

\section{Sequential Extraction Efficiency (SEE) and Quality Control (QC)}

The sequential extraction efficiency SEE (\%) for a given metal was calculated as the ratio of the sum of the metal content in all extracted fractions $\left(\mathrm{C}_{1}\right)$ and it concentration obtained by three strong acids digestion $\left(\mathrm{C}_{2}\right)$ brought to 100 (Equation 1). The digestion of a certified reference material GBW07309 (GSD-9, grey sediment) $(0.5 \mathrm{~g})$ and blank were also performed for quality control. The recovery ratios $(\mathrm{R})$ were calculated as the ratio of the extracted concentration (Cex) and its corresponding reference value (Cs) brought to 100 (Equation 2). R values were comprised between $88.5 \%$ and $105.5 \%$ (Table 3 ). The supplement concentration responsible of $\mathrm{R}$ values greater than $100 \%$ could be attributed to some slight errors and uncertainty during manipulation and the preparation of samples:

$\operatorname{SEE}(\%)=\frac{C 1}{C 0} \times 100$ 


$$
R(\%)=\frac{C e x}{C s} \times 100
$$

\section{Pollution Indicators}

To better understand and assess the impact of pollutants in the environment, several parameters such as Mobility Factors (MF), Pollution Indexes (PI), Pollution Load Index (PLI) and Enrichment Factor (EF) were evaluated.

\section{Mobility Factors (MF)}

MF is defined as the ability of a metal to pass from the most stable form to unstable ones, where it is less energetically retained (Achiba et al., 2010). In order to access the mobility and bioavailable metals in soil, the MF was calculated as a ratio of metal concentration in the mobile fraction to the sum of all fractions: High MF values is interpreted as symptoms of relatively high mobility and biological availability of heavy metals in soils (Achiba et al., 2010):
$M F=\frac{\sum_{i=1}^{3} F i}{\sum_{i=1}^{6} F i} \times 100$

\section{Pollution Indexes (PI)}

Pollution Index (PI) is used to provide a relative ranking of contamination levels. It is calculated according to (Lee et al., 2006) via the equation (Equation 4) below; where $C j$ is the concentration of a given element $j$ in soil samples $\left(\mathrm{mg} \mathrm{kg}^{-1}\right)$ and Coj is its corresponding concentration $\left(\mathrm{mg} \mathrm{kg}^{-1}\right)$ in a reference soil or sludge. In this study, the reference sludge for the environment most protective European countries such as Netherlands, Sweden and Denmark (EC, 2001; Salado et al., 2008; Olofsson et al., 2012) (Table 2) was considered in the present study:

$$
P I=\frac{C j}{C o j}
$$

\begin{tabular}{|c|c|c|c|}
\hline Fractions & Reagents & Temperature & Duration \\
\hline F1 (Water Soluble) & $\begin{array}{l}1 \mathrm{~g} \text { dry ground and sieved sample }+15 \mathrm{~mL} \\
\text { reagent water. }\end{array}$ & Ambient & $2 \mathrm{~h}$ \\
\hline $\mathrm{F}_{2}$ (Exchangeable) & $\mathrm{F} 1$ residue $+8 \mathrm{~mL}$ of $1 \mathrm{M} \mathrm{MgCl}_{2}(\mathrm{pH} 7.0)$ & Ambient & $1 \mathrm{~h}$ \\
\hline F3 (Carbonate-Bound) & $\begin{array}{l}\text { F2 residue }+8 \mathrm{~mL} \text { of } 1 \mathrm{M} \text { Ammonium } \\
\text { acetate (Adjusted to } \mathrm{pH} 5.0 \text { with Acetic acid) }\end{array}$ & Ambient & $5 \mathrm{~h}$ \\
\hline F4 (Fe-Mn Oxides-Bound) & $\begin{array}{l}\mathrm{F} 3 \text { residue }+20 \mathrm{~mL} 0.04 \mathrm{M} \mathrm{NH}_{4} \mathrm{OH} . \mathrm{HCl} \text { in } \\
25 \% \text { (v: v) Acetic acid with occasional agitation. }\end{array}$ & $96^{\circ} \mathrm{C}$ & $6 \mathrm{~h}$ \\
\hline \multirow[t]{3}{*}{ F5 (Organic-Bound) } & $\begin{array}{l}\mathrm{F} 4 \text { residue }+3 \mathrm{~mL} \text { of } 0.02 \mathrm{M} \text { Nitric acid and } 5 \\
\mathrm{~mL} \text { of } 30 \% \mathrm{H}_{2} \mathrm{O}_{2} \text { (adjusted to } \mathrm{pH} 2 \text { with } \mathrm{HNO}_{3} \text { ) } \\
\text { with occasional agitation. }\end{array}$ & $85^{\circ} \mathrm{C}$ & $3 \mathrm{~h}$ \\
\hline & $\begin{array}{l}\text { A second } 3 \mathrm{~mL} \text { aliquot of } 30 \% \mathrm{H}_{2} \mathrm{O}_{2}(\mathrm{pH} 2 \\
\text { with } \mathrm{HNO}_{3} \text { ) heat at } 85^{\circ} \mathrm{C} \text { with intermittent } \\
\text { agitation. Then Cool }\end{array}$ & $85^{\circ} \mathrm{C}$ & $3 \mathrm{~h}$ \\
\hline & $\begin{array}{l}\text { Add } 5 \mathrm{~mL} \text { of } 3.2 \mathrm{M} \mathrm{NH}_{4} \mathrm{OAc} \text { in } 20 \%(\mathrm{v}: \mathrm{v}) \\
\mathrm{HNO}_{3} \text {, make up the volume to } 20 \mathrm{~mL} \text { reagent } \\
\text { water and agitated continuously }\end{array}$ & Ambient & $30 \mathrm{~min}$ \\
\hline F6 (Residual) & $\begin{array}{l}\text { F5 residue after drying transverse to conical } \\
\text { flask }+10 \mathrm{~mL} \text { of } 7 \mathrm{M} \mathrm{HNO}_{3} \text { on a hot plate } \\
\text { for } 6 \text { hours. After evaporation at } 170^{\circ} \mathrm{C} \text {, } \\
1 \mathrm{~mL} \text { of } 2 \mathrm{M} \mathrm{HNO} \mathrm{HN}_{3} \text { was added and the residue } \\
\text { after dissolution was diluted to } 10 \mathrm{~mL} \text {. The } \\
\text { residue was washed with } 10 \mathrm{~mL} \text { reagent water. }\end{array}$ & Evaporation $170^{\circ} \mathrm{C}$ & $6 \mathrm{~h}$ \\
\hline
\end{tabular}

Table 1. Metals sequential extraction method according to Aikpokpodion et al. (2013)

Table 2. Standard heavy metals contents in the sludge in the EU countries with far more stringent limits than EU provisions (EC, 2001; Salado et al., 2008; Olofsson et al., 2012)

\begin{tabular}{lll}
\hline Elements & Concentration $\left(\mathrm{mg} \mathrm{kg}^{-1} \mathrm{DM}\right)$ & $\left.\mathrm{Average}^{(\mathrm{mg} \mathrm{kg}} \mathrm{kg}^{-1} \mathrm{DM}\right)$ \\
\hline $\mathrm{Cd}$ & $0.8-2$ & 1.4 \\
$\mathrm{Co}$ & $\mathrm{NR}$ & $\mathrm{NR}$ \\
$\mathrm{Cu}$ & $75-600$ & 337.5 \\
$\mathrm{Zn}$ & $300-800$ & 550 \\
$\mathrm{Ni}$ & $30-50$ & 40 \\
$\mathrm{Cr}$ & $75-100$ & 87.5 \\
$\mathrm{~Pb}$ & $100-120$ & 110 \\
$\mathrm{Mn}$ & $\mathrm{NR}$ & $\mathrm{NR}$ \\
$\mathrm{Fe}$ & $\mathrm{NR}$ & $\mathrm{NR}$ \\
\hline
\end{tabular}

NR - Not Reported 
Table 3. Physicochemical characterization total metals contents of the sludge

Metals contents and speciation $\left(\mathrm{mg} \mathrm{kg}^{-1} \mathrm{DM}\right)$

\begin{tabular}{|c|c|c|c|c|c|c|c|c|c|}
\hline \multirow{3}{*}{$\begin{array}{l}\text { Parameters } \\
\text { Values } \\
\text { Elements }\end{array}$} & \multirow{2}{*}{\multicolumn{2}{|c|}{$\begin{array}{l}\mathrm{pH} \\
---- \\
7.6\end{array}$}} & \multicolumn{3}{|c|}{$\mathrm{EC}\left(\mathrm{mS} \mathrm{cm}^{-1}\right)$} & \multicolumn{2}{|c|}{$\mathrm{OM}(\%)$} & \multicolumn{2}{|c|}{$\mathrm{TP}(\%)$} \\
\hline & & & 4.7 & & \multirow{2}{*}{$\begin{array}{l}\text { TS (\%) } \\
22.6 \\
\mathrm{Ni}\end{array}$} & \multicolumn{2}{|l|}{52.5} & \multicolumn{2}{|l|}{0.76} \\
\hline & $\mathrm{Cd}$ & $\mathrm{Co}$ & $\mathrm{Cu}$ & $\mathrm{Zn}$ & & $\mathrm{Cr}$ & $\mathrm{Pb}$ & $\mathrm{Fe}$ & $\mathrm{Mn}$ \\
\hline F1 & 0.40 & 1.10 & 20.6 & 49.1 & 16.2 & 12.2 & 3.6 & 163.1 & 30.1 \\
\hline F2 & 1.30 & 0.90 & 69.5 & 115.8 & 8.7 & 46.3 & 11.9 & 577.1 & 59.0 \\
\hline F3 & 9.40 & 2.80 & 360.1 & 95.7 & 29.3 & 27.3 & 37.9 & 164.0 & 15.3 \\
\hline F4 & 2.30 & 1.65 & 55.8 & 469.2 & 5.1 & 37.6 & 13.0 & 1630.8 & 156.6 \\
\hline F5 & 7.40 & 3.80 & 180.4 & 173.7 & 65.5 & 49.0 & 55.6 & 153.7 & 60.9 \\
\hline F6 & 3.80 & 7.40 & 77.9 & 355.6 & 34.4 & 98.2 & 13.8 & 446.5 & 63.7 \\
\hline $\mathrm{C} 1$ & 24.60 & 17.70 & 764.6 & 1259.2 & 159.4 & 270.6 & 136.1 & 3136.1 & 285.6 \\
\hline $\mathrm{C} 2$ & 27.10 & 18.60 & 777.1 & 1271.7 & 165.5 & 297.0 & 131.2 & 3184.0 & 394.2 \\
\hline Cs & 0.26 & 14.40 & 32.0 & 78.0 & 32.0 & 85.0 & 23.0 & - & 620.0 \\
\hline Cex & 0.27 & 15.20 & 28.8 & 80.3 & 30.9 & 80.6 & 23.5 & - & 610.1 \\
\hline SEE (\%) & 91.10 & 94.90 & 98.4 & 99.0 & 96.3 & 91.1 & 103.6 & 98.5 & 97.8 \\
\hline $\mathrm{R}(\%)$ & 103.80 & 105.50 & 90.0 & 102.9 & 96.5 & 88.5 & 102.2 & - & 98.3 \\
\hline
\end{tabular}

Note: $\mathrm{R}$ was not calculated for Fe because the concentration of free Fe wasn't reported in the standard material. SEE could be considered for it recovery appreciation. Cex and Cs are respectively the extracted concentration and it corresponding reference value in the standard sediment for a given metal

Table 4. Pollution factors

\begin{tabular}{lccrrrrrrr}
\hline Elements & $\mathrm{Cd}$ & $\mathrm{Co}$ & $\mathrm{Cu}$ & $\mathrm{Zn}$ & $\mathrm{Ni}$ & $\mathrm{Cr}$ & $\mathrm{Pb}$ & $\mathrm{Fe}$ & $\mathrm{Mn}$ \\
\hline EF & 5318.0 & 19.1 & 490.7 & 335.6 & 62.3 & 57.1 & 136.5 & 1.0 & 7.3 \\
MFs (\%) & 41.1 & 26.2 & 57.9 & 20.5 & 32.7 & 28.8 & 40.8 & 28.4 & 26.5 \\
PI & 19.3 & - & 2.3 & 2.3 & 4.1 & 3.4 & 28.9 & - & - \\
PLI & & & & & & & 3.4 & & \\
\hline
\end{tabular}

Note: PLI was calculate for $\mathrm{Cd}, \mathrm{Cu}, \mathrm{Zn}, \mathrm{Ni}, \mathrm{Cr}$ and $\mathrm{Pb}$

\section{Pollution Load Index (PLI)}

PLI is used to assess the overall pollution status for a given sample (Lee et al., 2006). In the current study, PLI was calculated according to (Tomlinson et al., 1980; Luo et al., 2012; Lu et al., 2014) equation (Equation 5). Seven levels of pollution were reported by Zhang et al. (2011): Background concentration (PLI $=0)$, unpolluted $(0<$ PLI $\leq 1)$, unpolluted to moderately polluted $(1<$ PLI $\leq 2)$, moderately polluted $(2<\mathrm{PLI} \leq 3)$, moderately to highly polluted $(3<\mathrm{PLI} \leq 4)$, highly polluted $(4<\mathrm{PLI} \leq$ $5)$ and very highly polluted (PLI $>5)$ :

$$
P L I=\sqrt[n]{P I 1 \times P I 2 \times P I 3 \times \ldots \times P I n}
$$

where, $n$ is the number of heavy metals.

\section{Enrichment Factor (EF)}

Enrichment Factor (EF) is used to apportion the sources of trace metals in the sediment, soil and biosolids. EF of an element is obtained by comparing the abundance of a given trace element in the sludge relative to that same trace element in a reference material. Specifically, the EF of an element $(\mathrm{X})$ is generally calculated relative to the average composition of crustal abundance (Taylor, 1964; Rudnick and Gao, 2003) using $\mathrm{Al}$ or $\mathrm{Fe}$ as the reference element (Y). In this study, EFs of selected elements relative to crustal abundance using $\mathrm{Fe}$ as the reference element were calculated according to the Equation 6 below:

$$
E F=\frac{(X / F e) \text { Sludge }}{(X / F e) \text { Crust }}
$$

\section{Statistical Analysis}

Origin 8 and SPSS 20.0 ANOVA one way were used for data analysis.

\section{Results and Discussion}

\section{Physicochemical Characterization}

The investigated dewatered sludge exhibit a slightly alkaline character $(\mathrm{pH}>6.5)$ and high electrical conductivity denoting high concentration of organic and inorganic ions such as $\mathrm{Cl}^{-}, \mathrm{Na}^{+}, \mathrm{K}^{+}, \mathrm{NH}_{4}^{+}, \mathrm{NO}_{3}^{-}, \mathrm{SO}_{4}{ }^{2-}$, $\mathrm{HCO}_{3}{ }^{-}$in the sludge; which does not favor plant growth despite it is rich in organic matter and phosphorous (Table 3). Indeed, in previous study (Marchese et al., 2008), it has been reported that high EC values from $2.5-3.0 \mathrm{mS}$ 
$\mathrm{cm}^{-1}$ is harmful for fruits and values between $4.5-5 \mathrm{mS}$ $\mathrm{cm}^{-1}$ is harmful for the stems; which result into the low germination rate, withering of the plants.

\section{Metal Contents}

Data (Table 3) showed varied range of metal contents in the sludge. Metals contents are as follow: 27.1, 18.6, 777.1, 1271.7, 165.5, 297.0, 131.2, 3184.0 and $394.2 \mathrm{mg}$ $\mathrm{kg}^{-1} \mathrm{DM}$ for $\mathrm{Cd}, \mathrm{Co}, \mathrm{Cu}, \mathrm{Zn}, \mathrm{Ni}, \mathrm{Cr}, \mathrm{Pb}, \mathrm{Fe}$ and $\mathrm{Mn}$, respectively. It can thus been noted that $\mathrm{Cd}$ and $\mathrm{Co}$ are at the lowest concentration and $\mathrm{Cu}, \mathrm{Zn}$ and $\mathrm{Fe}$ at the highest concentration. The high concentration of $\mathrm{Fe}$ could be explained by the fact that $\mathrm{Fe}$ is known to be the earth crust's one of most abundant elements on one hand; and its wide utilization in our daily life on the other hand. The approach of EF is commonly to apportion the sources of trace metals in the sediment, soil and biosolids. As shown in the Table 4, no element shows consistently an $\mathrm{EF}<1$; enrichment values are greater than 10 except for $\mathrm{Mn}$ (5318.0, 19.1, 490.7, 335.6, 62.3, 57.1, 136.5 and 7.3, respectively for $\mathrm{Cd}, \mathrm{Co}$, $\mathrm{Cu}, \mathrm{Zn}, \mathrm{Ni}, \mathrm{Cr}, \mathrm{Pb}$ and $\mathrm{Mn}$ ). This suggests anthropogenic sources of elements than crustal source (Upadhyay et al., 2011). Co is commonly used in ceramic and glass materials. It can also be found in rechargeable batteries and electrical and electronic appliances. To promote growth rate, $\mathrm{Zn}$ and $\mathrm{Cu}$ are used as macronutrient elements in foodstuff additives (Xiong et al., 2010), which resulted to their accumulation in the sludge via excreta. In addition, other sources such as galvanized materials and car washes were reported for $\mathrm{Zn}$ and leaching from the newer plumbing systems was reported as the source for $\mathrm{Cu}$ (Sörme and Lagerkvist, 2002; Rule et al., 2006). $\mathrm{Ni}, \mathrm{Cr}, \mathrm{Pb}$ and $\mathrm{Mn}$ are detected at moderate concentration. The used of $\mathrm{Cd}, \mathrm{Ni}$ and $\mathrm{Cr}$, as microfunction elements in additives to enhance muscle productivity and immunity to diseases (Li et al., 2010); could explained their accumulation in the sludge. To better understand and appreciate the level of the metals in the sludge, comparison of their concentration in the sewage sludge and their corresponding value in the recommended reference biosolids (Table 2) is needed. Thus, although $\mathrm{Cd}$, owns the lowest concentration in the biosolids compared to others elements, it is at the very high concentration in the sludge as it value is fixed at $<2$ $\mathrm{mg} \mathrm{kg}{ }^{-1} \mathrm{DM}$ in the recommended reference biosolids (EC, 2001; Salado et al., 2008; Olofsson et al., 2012). $\mathrm{Cu}, \mathrm{Zn}, \mathrm{Ni}, \mathrm{Cr}$ and $\mathrm{Pb}$ concentrations are also beyond the recommended values. As a consequence the use of such sludge in agricultural lands would lead to metals spreading and accumulation in the soil. The sequential chemical fractionation of metals carried out in the sludge (discussed below), provided more information and permitted to better appreciate and access the environmental eco-toxicological risk; as the bioavailability and toxicity of heavy metals in the environment depends on their chemical forms (Filgueiras et al., 2004). ANOVA one way statistical analysis revealed significant variation between metals concentration in the sludge $(p<0.05)$. This suggests that metals in the sewage sludge may have some sources in common. Only $\mathrm{Cd}$ and $\mathrm{Co}$ did not show any dependency ( $p=0.858)$ suggesting the possibility of not having a common source.

\section{Sequential Extraction and Eco-Toxicological Risks}

The results of the sequential fractionation of metals in term of $\mathrm{mg} \mathrm{kg}^{-1} \mathrm{DM}$ is shown in the Table 2 . However, for better and easier appreciation of metals' level in the sludge, we are going to talk in the term of percentage (Fig. 1). Data showed that chemical forms distribution of metals varies from one to another. $\mathrm{Cd}, \mathrm{Cu}$, $\mathrm{Ni}$ and $\mathrm{Pb}$ are predominant in carbonates and organic bonds forms (F3 and F5), their concentration reached (34 and $27 \%),(46 \%$ and $23 \%),(18$ and $39 \%)$ and (29 and $42 \%$ ), respectively. It is widely said that organic bonds metals are relatively stable; however, under oxidizing condition which lead into the degradation of organic maters, metals could be released (Tessier et al., 1979) and easily be available for plants uptake. As it was predictable, $\mathrm{Zn}, \mathrm{Fe}$ and $\mathrm{Mn}$ are predominately bonded to iron and manganese (F4): 37\%, 51 and 40\%, respectively. F4 is known as reducible fraction (ÁlvarezValero et al., 2009) can easily be reduced and converted to exchangeable fraction; especially in anaerobic condition as it use to be in agricultural soil. As a consequence, due attention should be paid to metals stabilization in the sewage sludge to enhance and promote its agricultural use. $\mathrm{Co}$ and $\mathrm{Cr}$ are strongly bonded to silicates particles (F6): $44.6 \%$ and $42 \%$, respectively. It can also be noted that remarkable proportion, up to 23,29 and $24.5 \%$ of $\mathrm{Cd}, \mathrm{Zn}$ and $\mathrm{Ni}$, respectively are bonded to silicates particles. Otherwise, F1 and F2 fractions of metals are the lowest; nevertheless, their sum reached up to $5 \%(\mathrm{Cd})$ to $20 \%$. Such varied distribution of metals in the sludge has a very strong influence on the pollution indicators. Indeed, MFs PI and PLI widely vary from one metal to another (Table 4). Except $\mathrm{Zn}$, all others metals MF is beyond $20 \%$, this reveals the instability of metals and their potential mobility and migration in the sludge. $\mathrm{Cu}$ is the most mobile metal in the sludge $(\mathrm{MF}=58 \%)$ followed by $\mathrm{Cd}(41 \%), \mathrm{Pb}(40.8 \%)$ and $\mathrm{Ni}(32.7 \%)$. $\mathrm{Co}, \mathrm{Cr}, \mathrm{Fe}$ and $\mathrm{Mn}$ tend to exhibit similar mobility with $\mathrm{MF}$ ranging 26-29\%. In the soil, F1, F2 and F3 fractions of metals are very sensitive to the environmental conditions $(\mathrm{pH}$ and Temperature) (Achiba et al., 2010; Mingot et al., 1995). As a consequence these elements can easily be released to the environment and uptake by plants. 


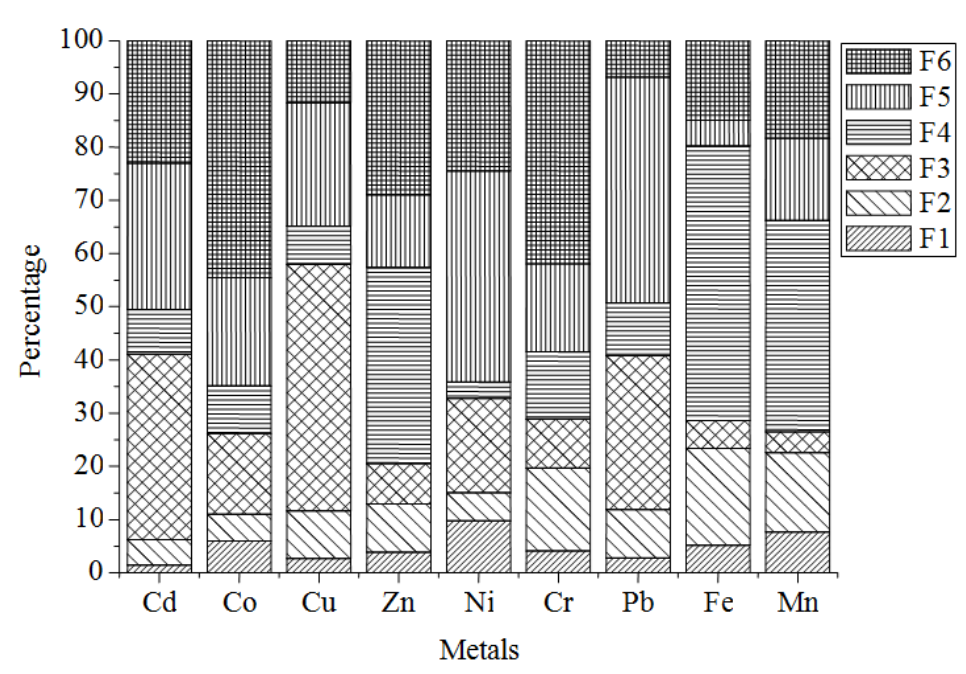

Fig. 1. Percentage distribution of different fractions of studied metals in the sludge

Moreover, the level of pollution's risk by metals is highlighted by the Pollution Index (PI). PI data showed that the application of such sludge in agricultural soil, would lead to a heavy $\mathrm{Cd}$ and $\mathrm{Pb}$ pollution (Lee et al., 2006) due to their high PI value (19.3 and 28.9, respectively). Repeated land application of such sludge would cause severe heavy metals pollution; as the PLI value (3.4) already indicated moderate heavy metals pollution of the sludge (Zhang et al., 2011).

\section{Conclusion}

Treated sewage sludge's physicochemical characterization, heavy metals contents determination and chemical fractionation have been investigated. The main conclusions are as follow:

- Sewage sludge is slightly alkaline and exhibited high electrical conductivity $\left(\mathrm{EC}>4 \mathrm{mS} \mathrm{cm}^{-1}\right)$

- Heavy metals concentration are at high level concentration beyond the recommended values in the sewage sludge

- Metals exhibit very high mobility with MFs ranging 20 to $41 \%$, mainly for $\mathrm{Cd}, \mathrm{Cu}, \mathrm{Ni}$ and $\mathrm{Pb}$

- Land application of such sludge will lead to a severe secondary environmental pollution, with its various negative impacts on the ecosystem

The improvement of the treatment process is highly recommended for better metals' stabilization within sludge before agricultural use or land application.

\section{Acknowlegement}

The authors acknowledged the finacial grant from the ministry of High Education and Scientific Research of the republic of Benin.

\section{Author's Contributions}

Fidèle Suanon, Lyde A.S. Tomètin and Ignace C. Agani: Equally contributed in designing and performing the experiments, samples analysis, data analysis, manuscript writing and the manuscript reviewing all through the publication process.

Biaou Dimon, Daouda Mama and Eni Coffi Azandegbe: Equally contributed in designing the experiments, data analysis, manuscript writing and reviewing during the publication process.

\section{Conflict of Interest}

This manuscript is original and contains not any published material. The corresponding author confirms that all of the others authors have read and approved the manuscript and thus declare no conflicts of interest.

\section{References}

Achiba, W.B., A. Lakhdar, N. Gabteni, G.D. Laing and M. Verloo et al., 2010. Accumulation and fractionation of trace metals in a Tunisian calcareous soil amended with farmyard manure and municipal solid waste compost. J. Hazard. Mater., 176: 99-108. DOI: 10.1016/j.jhazmat.2009.11.004

Aikpokpodion, P.E., L. Lajide and A.F. Aiyesanmi, 2013. Characterization of heavy metal fractions in agrizcultural soils using sequential extraction technique. World J. Agric. Sci., 9: 45-52.

Álvarez-Valero, A.M., R. Sáez, R. Pérez-López, J. Delgado and J.M. Nieto, 2009. Evaluation of heavy metal bioavailability from Almagrera pyrite-rich tailings dam (Iberian Pyrite Belt, SW Spain) based on a sequential extraction procedure. J. Geochem. Explorat., 102: 87-94. DOI: 10.1016/j.gexplo.2009.02.005 
Chipasa, K.B., 2003. Accumulation and fate of selected heavy metals in a biological wastewater treatment system. Waste Manage., 23: 135-143.

DOI: 10.1016/S0956-053X(02)00065-X

Chu, L.B., S.T. Yan, X.H. Xing, X.L. Sun and B. Jurcik, 2009. Progress and perspectives of sludge ozonation as a powerful pretreatment method for minimization of excess sludge production. Water Res., 43: 1811-1822.

DOI: $10.1016 /$ j.watres.2009.02.012

Dong, B., X. Liu, L. Dai and X. Dai, 2013. Changes of heavy metal speciation during high-solid anaerobic digestion of sewage sludge. Bioresour. Technol., 131: 152-158. DOI: 10.1016/j.biortech.2012.12.112

EC, 2001. Disposal and recycling routes for sewage sludge. Part 2- Regulatory report. European Comission, DG Environment, Office for Official Publications of the European Communities.

Filgueiras, A.V., I. Lavilla and C. Bendicho, 2004. Evaluation of distribution, mobility and binding behaviour of heavy metals in surficial sediments of Louro River (Galicia, Spain) using chemometric analysis: A case study. Sci. Total Environ., 330: 115-129. DOI: 10.1016/j.scitotenv.2004.03.038

Gao, P.C., X.B. Tang, Y.A. Tong and Y.X. Chen, 2008. Application of sewage sludge compost on highway embankments. Waste Manage., 28: 1630-1636. DOI: 10.1016/j.wasman.2007.08.005

Kelter, P.B., J. Grundman, D.S. Hage, J.D. Carr and C.M. Castro-Acuña, 1997. A discussion of water pollution in the United States and Mexico; with high school laboratory activities for the analysis of lead, atrazine and nitrate. J. Chem. Educ., 74: 1413-1421. DOI: $10.1021 / \mathrm{ed} 074 \mathrm{p} 1413$

Lee, I. and J.I. Han, 2013. The effects of wasteactivated sludge pretreatment using hydrodynamic cavitation for methane production. Ultrason. Sonochem., 20: 1450-1455. DOI: $10.1016 /$ j.ultsonch.2013.03.006

Lee, C.S., X.D. Li, W.Z. Shi, S.C. Cheung and I. Thornton, 2006. Metal contamination in urban, suburban and country park soils of Hong Kong: A study based on GIS and multivariate statistics. Sci. Total Environ., 356: 45-61.

DOI : 10.1016/j.scitotenv.2005.03.024

Li, Y.X., X. Xiong, C.Y. Lin, F.S. Zhang and W. Li et al., 2010. Cadmium in animal production and its potential hazard on Beijing and Fuxin farmlands. J. Hazard. Mater., 177: 475-480.

DOI: $10.1016 /$ j.jhazmat.2009.12.057

Lu, X.W., X.L. Zhang, L.Y. Li and H. Chen, 2014. Assessment of metals pollution and health risk in dust from nursery schools in Xi'an, China. Environ. Res., 1281: 27-34.

DOI: $10.1016 /$ j.envres.2013.11.007
Luo, X.S., S. Yu, Y.G. Zhu and X.D. Li, 2012. Trace metal contamination in urban soils of China. Sci. Total Environ., 421-422: 17-30.

DOI: $10.1016 /$ j.scitotenv.2011.04.020

Marchese, M., R. Tuttobene, A. Restuccia, A.M.G. Longo and G. Mauromicale et al., 2008. Effects of electrical conductivity of irrigation water on the growth and production of Solanum lycopers icum L. var. ceras iforme grown in greenhouse. Opt. Méditerranéennes A, 84: 311- 315.

McBride, M.B., 1995. Toxic Metal accumulation from agricultural use of sludge: Are USEPA regulations protective? J. Environ. Q., 24: 5-18. DOI: $10.2134 /$ jeq1995.00472425002400010002x

Mingot, J.I., A. Obrador, J.M. Alvarez and M.I. Rico, 1995. Acid extraction and sequential fractionation of heavy metals in water treatment sludges. Environ. Tech., 16: 869-876. DOI: $10.1080 / 09593331608616325$

Olofsson, U., A. Bignert and P. Haglund, 2012. Timetrends of metals and organic contaminants in sewage sludge. Water Res., 46: 4841-4851.

DOI: $10.1016 /$ j.watres.2012.05.048

Roca-Pérez, L., C. Martínez, P. Marcilla and R. Boluda, 2009. Composting rice straw with sewage sludge and compost effects on the soil-plant system. Chemosphere, 75: 781-787.

DOI: 10.1016/j.chemosphere.2008.12.058

Rudnick, R.L. and S. Gao, 2003. The composition of the continental crust.

Rule, K.L., S.D.W. Comber, D. Ross, A. Thornton and C.K. Makropoulos et al., 2006. Diffuse sources of heavy metals entering an urban wastewater catchment. Chemosphere, 63: 64-72.

DOI: 10.1016/j.chemosphere.2005.07.052

Salado, R., E. Daly, D. Vencovsky, T. Zamparutti and R. Palfrey, 2008. Environmental, economic and social impacts of the use of sewage sludge on land. Consultation report on options and impacts prepared by RPA, Milieu Ltd and WRc for the European Commission, DG Environment under Study Contract DG ENV.G.4/ETU/2008/0076r.

Sörme, L. and R. Lagerkvist, 2002. Sources of heavy metals in urban wastewater in Stockholm. Sci Total Environ., 298 : 13-145. DOI: $10.1016 / \mathrm{S} 0048-9697(02) 00197-3$

Taylor, S.R., 1964. Abundance of chemical elements in the continental crust: A new table. Geochim. Cosmochim. Acta 28: 1273-1285. DOI: 10.1016/0016-7037(64)90129-2

Tessier, A., P.G.C. Campbell and M. Bission, 1979. Sequential extraction procedure for the speciation of particulate trace metals. Anal. Chem., 51: 844-858. DOI: $10.1021 / \mathrm{ac} 50043 \mathrm{a} 017$ 
Tomlinson, D.L., J.G. Wilson, C.R. Harris and D.W. Jeffrey, 1980. Problems in the assessment of heavy-metal levels in estuaries and the formation of a pollution index. Helgoländer Meeresun., 33: 566-575. DOI: 10.1007/BF02414780

Upadhyay, N., A. Clements, M. Fraser and P. Herckes, 2011. Chemical speciation of PM2.5 and PM10 in south phoenix, AZ. J. Air Waste Manage. Assoc., 61: 302-310. DOI: 10.3155/1047-3289.61.3.302

WEF and NACWA, 2013. A guide to understanding biosolids issues. Water Environment Federation and NACWA.
Xiong, X., Y.X. Li, W. Li, C.Y. Lin and W. Han et al., 2010. Copper content in animal manures and potential risk of soil copper pollution with animal manure use in agriculture. Resour. Conserv. Recycl., 54: 985-990. DOI: 10.1016/j.resconrec.2010.02.005

Zhang, C., Q. Qiao, J.D. Piper and B. Huang, 2011. Assessment of heavy metal pollution from a Fesmelting plant in urban river sediments using environmental magnetic and geochemical methods. Environ. Pollut., 159: 3057-3070.

DOI: $10.1016 /$ j.envpol.2011.04.006 